Interdyscyplinarny charakter badań językowych, red. J. Małocha, Kraków 2017, s. 39-54

DOI: http://dx.doi.org/10.15633/9788374386081.03

Agnieszka Kościńska

\title{
W poszukiwaniu siebie w muzyce - rola bluesa w kształtowaniu tożsamości mieszkańców Południa Stanów Zjednoczonych
}

Człowiek żyje prawdziwie ludzkim życiem dzięki kulturze. [...]

Kultura jest właściwym sposobem istnienia i bytowania człowieka. [...]

Kultura jest tym, przez co człowiek staje się bardziej człowiekiem:

bardziej „jest” [...] Naród bowiem jest tą wielką wspólnotą ludzi,

którą łączą różne spoiwa, ale nade wszystko kultura.

Naród istnieje „z kultury” i „dla kultury”. [...] Jestem synem narodu, który

przetrwał najstraszliwsze doświadczenia dziejów,

którego sąsiedzi wielokrotnie skazywali na śmierć -

a on pozostał przy życiu i pozostał sobą. Zachował własną tożsamość

i zachował pośród rozbiorów i okupacji własną suwerenność jako naród -

nie biorąc za podstawę przetrwanie jakichkolwiek innych środków fizycznej potęgi

jak tylko własna kultura, która się okazała w tym przypadku

potęgą większą od tamtych potęg [...]

Istnieje podstawowa suwerenność społeczeństwa,

która wyraża się w kulturze narodu ${ }^{1}$.

Kwestia tożsamości człowieka stanowi jedno z najważniejszych zagadnień $w$ takich dziedzinach nauki jak psychologia czy socjologia. Problem tożsamości można zaobserwować w interakcjonizmie społecznym, który

\footnotetext{
${ }^{1}$ Jan Paweł II, Pamięć i tożsamość, Kraków 2005, s. 89n.
} 
postrzega ją jako zjawisko wywodzące się z oddziaływania różnych czynników. W tej koncepcji istota ludzka to samodzielny, świadomy partner zarówno w kontakcie z innymi ludźmi, jak i otaczającą go kulturą. W ujęciu prezentowanym przez Normana Goodmana rozwój tożsamości odbywa się dzięki socjalizacji, czyli procesowi społecznych interakcji ${ }^{2}$. Z kolei Talcott Parsons twierdził, że tożsamość indywidualna kształtuje uczestnictwo człowieka w życiu społecznym ${ }^{3}$.

Termin „tożsamość” w słowniku języka polskiego wyjaśniony jest jako świadomość siebie, pewne cechy, właściwości pozwalające zidentyfikować daną osobę. Pojęcie to funkcjonuje także w odniesieniu do ludzi jako zbiorowości i w tym przypadku rozumiane jest jako świadomość wspólnych cech i poczucie jedności ${ }^{4}$. Z podanych definicji, jak również sposobów postrzegania tożsamości przez socjologów wynika więc, że może ona być rozumiana różnorako i nie jest pojęciem odnoszącym się jedynie do jednostki. Celem niniejszego artykułu jest przedstawienie historii jednego z najpopularniejszych stylów muzycznych - bluesa właśnie poprzez prezentację powiązania kultury danej społeczności z jej tożsamością.

\section{Tło historyczne}

Aby zrozumieć historię i kontrowersje związane z powstaniem bluesa, należy sięgnąć głęboko do historii niewolnictwa na terenie Stanów Zjednoczonych, ze szczególnym uwzględnieniem jego południowych obszarów. Stany tzw. Głębokiego Południa (pięć stanów: Alabama, Georgia, Louisiana, Missisipi oraz Tennessee) obecnie utożsamiane są z bogactwem kulturowym, również w dziedzinie muzyki ${ }^{5}$. Z obszarów tych wywodzą się gatunki muzyczne, które zdobyły popularność nie tylko na terenie

\footnotetext{
2 Zob. N. Goodman, Wstęp do socjologii, przekł. J. Polak, J. Ruszkowski, U. Zielińska, Poznań 2009, s. 83.

${ }^{3}$ Zob. M. Dziewiecki, Psychologiczne interpretacje tożsamości człowieka, http://www. opoka.org.pl/biblioteka/I/IP/tozsamosc_czlowieka.html (20.11.2016).

${ }^{4}$ Słownik Języka Polskiego, http://sjp.pwn.pl/slownik/2530211/to\%C5\%BCsamo\%C5\%9B\%C4\%87 (03.11.2016).

${ }^{5}$ Zob. The Deep South States, http://www.deep-south-usa.com/ (02.10.2016).
} 
USA, ale również poza jego granicami. Są to tereny, których historia, kultura, tożsamość i piękno odróżniają je od innych amerykańskich stanów. Historycznie patrząc, były to obszary rolnicze, w których najbardziej zamożną warstwę stanowili biali plantatorzy ziemscy. Wykorzystywali oni niewolników do ciężkiej pracy fizycznej na plantacjach ${ }^{6}$. W takich warunkach najpierw wśród ludzi przywiezionych z różnych części Afryki, a później wśród pokolenia urodzonego już na terenie USA powoli wymierał afrykański folklor, zwyczaje i obyczaje. Powstawała nowa kultura, powiązana z warunkami życia w Stanach Zjednoczonych, oparta na języku angielskim i w swoich utworach opisująca aktualne problemy.

Mimo likwidacji niewolnictwa w 1865 roku w wyniku XIII poprawki do konstytucji sytuacja Afroamerykanów nie uległa znaczącej poprawie. Pojawiła się bowiem nowa forma rasowej nierówności, a wynik wojny secesyjnej nie zachęcił białych obywateli Południa do akceptacji wprowadzanego stanu rzeczy. Prawa wyborcze nadane czarnoskórym rok później dodatkowo antagonizowały społeczności lokalne. W odpowiedzi na te zmiany poszczególne stany USA zaczęły wkrótce uchwalać akty ograniczające wolność Afroamerykanów, które obecnie znane są pod nazwą praw Jima Crowa ${ }^{7}$. Rzeczone akty prawne przyczyniły się do kontynuacji podziału rasowego w USA między innymi poprzez wprowadzenie separacji w środkach transportu publicznego, restauracjach, a nawet toaletach. W efekcie zmienionego prawodawstwa pojawiały się dzielnice, gdzie Afroamerykanie nie mogli zamieszkać. Sytuacja ta uległa przekształceniu dopiero w latach 50. ubiegłego stulecia, kiedy to Sąd Najwyższy zaczął rozpatrywać poszczególne zakazy i uznawać je za niekonstytucyjne. Rozpoczęła się epoka zmian i wolności.

${ }^{6}$ Szersze rozważania na temat rozwoju niewolnictwa w USA - zob. C. Berkin, Making America a history of the US, Wadsworth 2011, s. 299-301, 310-311; I. Berlin, Pokolenia $w$ niewoli. Historia niewolnictwa $w$ Ameryce Pónocnej, Warszawa 2010; D. King, „The World's Against Me As A Black Man”. Charles Mingus and Segregated America, „Journal of Historical Sociology" 13 (2000) nr 1, s. 54-77; M. J. Rozbicki, Narodziny narodu, Warszawa 1991, s. 100-126, 301-321; I. Rusinowa, Tom czy Sam. Z dziejów Murzynów w Ameryce Pólnocnej, Warszawa 1983.

7 Już sama nazwa tych praw była obraźliwa dla Afroamerykanów, ponieważ wyrażenie Jim Crow nawiązuje do karykatury czarnoskórego przedstawianego w sztukach teatralnych i tłumaczone było jako „czarnuch” (z ang. Negro). 


\section{Blues - definicja terminu i propozycje genezy zjawiska}

Pod koniec XIX wieku na terenach Głębokiego Południa Stanów Zjednoczonych powstała muzyka, która wywodziła się z pieśni religijnych, piosenek improwizowanych i śpiewanych w trakcie prac fizycznych (tzw. field hollers) ${ }^{8}$, a także prostych rymowanych ballad $\mathrm{z}$ fabułą. Twórcami i wykonawcami bluesa byli więc nie tylko obecni, ale także byli niewolnicy oraz czarnoskórzy poddzierżawcy ziemi, wnoszący opłatę za użytkowany grunt w zebranych plonach.

I taka teoria przedstawiania jest $\mathrm{w}$ wielu publikacjach na temat historii bluesa. Postrzegano go zatem jako muzykę folkową, o charakterze niekomercyjnym, wypływającą z podziałów w społeczeństwie i zapoczątkowaną w tradycji przekazu ustnego. Badacze folkloru Południa widzieli w nim formę opowiadania historii wcześniej już usłyszanych, muzykę wywodzącą się zarówno z hymnów religijnych, jak i śpiewów świeckich lub też element muzyki murzyńskiej z ponaddwustuletnią tradycją. W bluesie dopatrywano się także wyrazu tęsknoty za domem w znaczeniu przenośnym. Propagowano również tezę, iż powstał on bezpośred nio po wojnie secesyjnej jako - dość tradycyjna w swoim charakterze - forma celebrowania otrzymanej wolności. Elementem wspólnym była tylko jedna teza: blues to muzyka Południa rolniczego, wyrażająca tożsamość ludzi zamieszkujących ten rejon. To założenie wsparte zostało obecnie poprzez wyniki badań nad kulturą amerykańską, w które zaangażowali się znawcy folkloru i muzykologii, jak również socjolodzy.

${ }^{8}$ Zob. Field Hollers, http://northbysouth.kenyon.edu/2002/Music/Pages/fieldhollers. htm (13.11.2016).

Field-hollers (ang. field - „pole”, hollers - „okrzyki”) powstały na plantacjach ryżowych i bawełnianych w okresie niewolnictwa. Miały one na celu wzmocnienie współpracy, jak również osłabienie poczucia cierpienia związanego z uciskiem, jakiego doświadczali niewolnicy. Field-hollers tworzone były według określonego modelu: wezwanie - odpowiedź. Wykonanie rozpoczynał robotnik otaczany przez innych szacunkiem, pozostali pracownicy odpowiadali mu w tym samym rytmie. Tematyka field-hollers różniła się w zależności od tego, kto je wykonywał. Murzyni przywiezieni z Afryki preferowali utwory, które przypominały im o ojczyźnie. Natomiast ci już urodzeni na terenie USA śpiewali o trudnym życiu w okresie niewolnictwa, jak również już po jego oficjalnym zniesieniu przez władze. Wzór rytmiczny i tematyka field-hollers są silnie obecne w bluesie. 
Wspólnie podkreślają oni znaczenie muzyki w kontekście społecznym i kulturowym? .

Czym zatem tak naprawdę był blues? Jak był on postrzegany przez jego twórców i artystów wykonujących ten rodzaj muzyki? Jak odbierali go słuchacze? W jednej ze swych wypowiedzi słynny czarnoskóry amerykański pisarz Ralph Waldo Ellison mówił, iż „blues to impuls do zachowania w pamięci bolesnych szczegółów i epizodów brutalnych doświadczeń w odczuwającej ten ból świadomości [...]. Jako forma, blues jest autobiograficzną kroniką osobistych klęsk wyrażonych w sposób liryczny"10. W ten sposób blues staje się sposobem wyrażania własnego ,ja”, osobistych przeżyći doświadczeń. Podobnego zdania była również znana amerykańska artystka bluesowa Alberta Hunter, która stwierdziła, iż „blues jest tym samym, czym mleko dla dziecka. Blues jest tym, czym dla pastora jest dusza. Śpiewamy bluesa, ponieważ nasze serca zostały zranione, a spokój naszych dusz został zakłócony" ${ }^{\prime 1}$. Zaś Morgan Freeman - słynny amerykański aktor urodzony w 1937 roku w Memphis (Tennessee) wyznał, iż bardzo lubi bluesa, ponieważ na nim się wychował ${ }^{12}$.

$\mathrm{Z}$ wypowiedzi tych wynika, iż blues rozumiany był jako narzędzie do wyrażania emocji i opisywania własnych historii. Muzyka ta jawi się

9 Jednym z badaczy analizujących model relacji, jakie zachodzą między muzyką a budowaniem zbiorowej tożsamości oraz pamięci, jest Ron Eyerman - autor książek z obszaru socjologii sztuki, jak również kultury i teorii rozwoju ruchów społecznych. Prowadzi on także badania dotyczące ruchu praw człowieka oraz roli niewolnictwa w tworzeniu tożsamości afroamerykańskiej. W oparciu o uzyskane wnioski opracował on model kultury i sztuki jako narzędzia służącego nie tylko mobilizacji danej grupy społecznej, ale także jako elementu służącego uspokajaniu nastrojów społecznych w obszarze zagadnień politycznych. Szczegółowy opis tegoż modelu, jak również badań poprzedzających jego opracowanie zob. R. Eyerman, Music in Movement: Cultural Politics and Old and New Social Movements, „Qualitative Sociology” 25 (2002) nr 3, s. 446n. Pogłębione rozważania na temat relacji występujących pomiędzy pochodzeniem rasowym, grupą etniczną oraz pochodzeniem społecznym a tworzeniem i wykonywaniem muzyki - zob. także: K. H. Marcus, Music and American Culture, „History Compass” 5/4 (2007), s. 1412-1430.

10 Tłumaczenie własne z: Ralph Ellison quotes, http://www.goodreads.com/author/quotes/7508.Ralph_Ellison (10.11.2016).

11 Tłumaczenie własne z: Blues quotes, http://www.brainyquote.com/quotes/keywords/ blues.html (02.11.2016).

${ }_{12}$ Tłumaczenie własne z: Blues quotes, http://www.brainyquote.com/quotes/keywords/ blues.html (02.11.2016). 
jako nieodłączna część losów ludzi ją tworzących oraz sprawia wrażenie wyrastającej z ich doświadczeń i przeżyć. Jako element składowy życia Afroamerykanów pełniła więc ważną rolę w kształtowaniu tożsamości zarówno mniejszych społeczności, jak również całych zbiorowości.

Za ojca bluesa uważany jest William Christopher Handy, który postrzegał go jako stan umysłu. Tłumaczył, iż mógł tworzyć swoje utwory tylko w momencie odczuwania emocji, jakie utożsamiał z tym stylem. W takim ujęciu blues można więc rozumieć jako odzwierciedlenie siebie, własnej tożsamości i historii swego życia zarówno w słowach utworów, jak również w ich linii melodycznej. Definicja ta znalazła uznanie również w oczach części badaczy folkloru, którzy widzieli w bluesie możliwość wyrażenia potrzeb społecznych, emocjonalnych, a także odwołanie się do korzeni afrykańskich. W efekcie takiego postrzegania niektórzy zaczęli dopatrywać się różnicy pomiędzy muzyką wykonywaną przed latami 20. ubiegłego stulecia i po tym okresie. Na tej podstawie wprowadzona została także różnica między bluesem folkowym a komercyjnym i rozpoczęły się dyskusje, co jest tym prawdziwym, a co fałszywym bluesem.

Debaty te już kilkanaście lat później budziły wiele kontrowersji. Alan Lomax z Biblioteki Kongresu stwierdził nawet, że idea czystych społeczności bluesowych jest iluzją, a tworzenie muzyki powinno być manifestacją procesów społecznych i ekonomicznych. W ten sposób uznał on wartość i rolę muzyki w procesie odzwierciedlania nastrojów społecznych panujących $\mathrm{w}$ danej grupie oraz wskazał na połączenie muzyki $\mathrm{z}$ innymi aspektami życia. Co ciekawe, dopiero w latach 90. ubiegłego stulecia dokładnie zbadano wczesną historię tzw. bluesa komercyjnego, odkrywając olbrzymi, a zapomniany już teatr afroamerykańśkiej rozrywki ${ }^{13}$.

W 2004 roku Elijah Wald - znany gitarzysta bluesowy oraz historyk muzyki - opublikował książkę Uciekając $z$ Delty. Robert Johnson a początki muzyki bluesowej ${ }^{14}$. Wysnuł w niej tezę, iż początków bluesa na-

${ }^{13} \mathrm{~W}$ trakcie tych badań uzyskano informację o pokoleniu profesjonalnych twórców i kompozytorów bluesa sprzed 1920 roku.

${ }_{14}$ Tłumaczenie własne tytułu z: Escaping the Delta. Robert Johnson and the Invention of the Blues. 
leży upatrywać w wodewilach oraz tzw. medicine shows ${ }^{15}$. Te ostatnie ze współczesnego punktu widzenia można uznać za formę akwizycji, jako że ich celem była sprzedaż produktów o charakterze „leczniczym”. Jednakże poza przeznaczeniem handlowym miały one do wypełnienia również funkcję typowo rozrywkową. Przedstawienie takie mogło bowiem trwać do dwóch godzin i tworzyło je około dziesięciu elementów. W jego skład wchodziły zarówno wykłady, opowiadanie dowcipów, występy magików i sztuczki, jak również utwory muzyczne. Częstym elementem były też tzw. freak shows ${ }^{16}$, w których występowali ludzie bądź zwierzęta $z$ anomaliami fizycznymi. Przeważnie całe przedstawienie rozpoczynało się występem solo na banjo lub też wspólnym tańcem i śpiewem, w którym brali udział wszyscy aktorzy. Im bardziej pokaz był atrakcyjny dla widza, tym łatwiej było osiągnąć cel - sprzedać „lek”. Medicine shows zyskały olbrzymią popularność wśród ludności. Jako forma rozrywki miały one funkcję nie tylko relaksującą, ale także spajającą daną społeczność, budującą relacje wśród jej członków i tym samym wzmacniającą proces socjalizacji, który był niezbędny do rozwoju tożsamości.

Wald stwierdził, iż pierwsze pokolenie artystów bluesowych nauczyło się tej muzyki właśnie od wykonawców wodewilowych. Jednakże nie przekreślił on całkowicie występowania powiązań z muzyką lokalną, która według niego mogła poprzedzać bluesa i wpływać na jego twórców. Wnioski przedstawiane przez Elijaha Walda pokrywają się z wynikami ostatnich badań naukowych, które stawiają znak zapytania odnośnie do ludowego pochodzenia bluesa ze względu na fakt, że historia jego komercyjnej odmiany datuje się na pierwszą dekadę XX wieku. Niezależnie od tego żaden $z$ badaczy nie zaprzecza, iż muzyka ta zawiera elementy tradycji i odzwierciedla odwieczne problemy człowieka. Jedynym, co stanowi problem przy założeniu, że blues był najpierw komercyjną formą rozrywki, jest wyjaśnienie, jak w takim razie został on tak głęboko powiązany z tradycją rolniczą?

W kontekście powyższych rozważań ważne wydaje się więc zrozumienie samej nazwy „blues” i jej znaczenia. Słowo to było używane już

\footnotetext{
15 About Medicine Shows, http://www.folkstreams.net/context,136 (30.10.2016).

${ }^{16}$ Freak - ang. „dziwak”, „oryginał”.
} 
we wczesnej fazie XIX wieku, kiedy to oznaczało stan melancholii, depresji, a później - nudy. Wydawać by się mogło zatem, że muzyka określana tym mianem winna mieć podobny wydźwięk. $Z$ takim rozumieniem nie współgra natomiast założenie o wodewilowej genezie bluesa. Może więc dopiero z upływem czasu termin ten zaczął być stosowany w odniesieniu do utworów muzycznych mających charakter melancholijny i smutny ${ }^{17}$.

Mimo kontrowersji związanych z samą genezą gatunku wszystkie utwory bluesowe mają cechy wspólne: specyficzne tempo oraz nierówny rytm. Pierwszy raz zostało to ukazane w drukowanej formie utworu I Got the Blues. Wkrótce zaś, w pierwszej połowie XX wieku, nadszedł pierwszy sukces artysty bluesowego - W.C. Handy'ego. Jego dzieła - Memphis Blues oraz St. Louis Blues - zainicjowały popularność tego gatunku w wymiarze komercyjnym, jak również wyznaczyły pewne standardy muzyki bluesowej. Oczywiście jednak treść tekstów i forma ich wykonania podlegały ciągłym modyfikacjom, uzależnionym od stylu wykonawców. Każdy z utworów miał więc pierwiastek autonomiczny, właściwy dla jego twórcy, poprzez który wyrażał on swoją tożsamość i uzewnętrzniał swoje przeżycia.

Pewne elementy - które stały się później charakterystyczne dla bluesa - obecne były również $\mathrm{w}$ dwóch innych rodzajach muzyki wykonywanej $w$ tamtych latach, a mianowicie $\mathrm{w}$ tzw. coon songs ${ }^{18}$ oraz ragtime. Ten ostatni na początku był muzyką taneczną, utożsamianą pierwotnie z dzielnicami prostytutek w społecznościach afroamerykańskich St. Loius oraz Nowego Orleanu. Natomiast pod pojęciem coon songs rozumiano wyjściowo utwory prezentujące rasistowskie i stereotypowe obrazy czarnoskórych. Do ich cech charakterystycznych należały między innymi: styl wypowiadania, a raczej wykrzykiwania słów, użycie regionalnych dialektów, ukierunkowanie się na wyrażanie smutku, melancholii

17 Informacje na temat terminologii muzycznej - zob. G. Dąbkowski, Europejska terminologia muzyczna, Kielce 1997, s. 63-65; Encyklopedii PWN. Muzyka, kompozytorzy $i$ wykonawcy prady i kierunki dzieła, Warszawa 2007, s. 111-112. Szczegółowe dane na temat historii bluesa, jak również jego związków z zagadnieniem segregacji rasowej zob. U. Adult, Black, White, and Blue: Racial Politics in B.B. King's Music from the 1960s, „The Journal of Popular Culture” 44 (2011) nr 2, s. 195-214.

${ }^{18}$ Coon - ang. „,czarnuch”. Zob. Coon, http://slownikhistoryczny.pl/angielsko-polski/ coon (10.08.2016). 
i zadumy, a także specyficzna, osobna i niezazębiająca się "relacja” na płaszczyźnie wykonawca-instrument. Ważną rolę odgrywały również elementy improwizacji, powiązane ze specyficzną wymową samogłosek takich jak ,a”, „u” oraz „,"19.

Kolejnym elementem tożsamości USA, który znalazł swoje odzwierciedlenie w muzyce bluesowej, jest twórczość religijna. Powiązanie z pieśniami tego typu jest dość wyraźnie widoczne, ponieważ - jak wynika ze słów utworu Memphis Blues - ten rodzaju muzyki miał w swoim założeniu brzmieć jak „pieśń żalu czarnego [człowieka]”20. Zaś zawodzące, tęskne tony nieobce były ówczesnej muzyce kościelnej, a wywołanie takiego efektu głosem umożliwiało wykorzystanie rozwiązań rozpowszechnionych już wcześniej wśród coon singers ${ }^{21}$. Pewne elementy bluesa zostały też zaczerpnięte $\mathrm{z}$ tradycji muzyki gospel. Zalicza się do nich m.in. podobne do skandowania wznoszenie i opadanie wysokości dźwięku i jego głośności oraz improwizacje. Biorąc pod uwagę powyższe czynniki, związek pomiędzy tymi dwoma rodzajami muzyki staje się oczywisty.

Historia bluesa wiąże się z jeszcze jednym aspektem kultury amerykańskiej - tzw. juke joints, czyli zalążkiem obecnych tanich barów. Powstały one po zniesieniu niewolnictwa na południowo-wschodnim obszarze USA i przeznaczone były dla Afroamerykanów pracujących na terenach wiejskich. Swoje początki zawdzięczają prawom Jima Crowa, które uniemożliwiały czarnym przebywanie w tych samych restauracjach i barach co biali. Juke joints powstawały zazwyczaj zaraz obok pól rolniczych, a ich właścicielami byli przeważnie imigranci lub ich bezpośredni potomkowie. Stanowiły miejsce spotkań, odpoczynku, jedzenia, picia oraz handlu. Można w nich było wysłuchać muzyki nie tylko na żywo, ale również z gramofonu, a później - z grającej szafy. W okresie prohibicji dawały możliwość nabycia bimbru, co jeszcze bardziej wpływało na negatywną ocenę tego rodzaju miejsc. Juke joints odegrały również ważną

19 Podobieństwa pomiędzy coon songs a bluesem wynikają też być może z faktu, iż wielu bluesmanów z lat 20. XX wieku rozpoczynało swoją karierę artystyczną jako wykonawcy coon songs.

20 Tłumaczenie własne z oryginalnego wyrażenie: „like a darkie sorrow song”.

${ }^{21}$ Wykonawca coon songs zwany był coon singer. 
rolę w kształtowaniu i propagowaniu tradycyjnej muzyki murzyńskiej. O ile bowiem początkowo miejsca te rozbrzmiewały dźwiękiem banjo oraz skrzypiec, o tyle wraz z upływem czasu pojawiły się tam ragtime, coon songs oraz blues. Co ciekawe, juke joints nadal można znaleźć na terenie biednych, rolniczych obszarów Południa ${ }^{22}$.

W ostatnich latach na podstawie analizy dokumentów i świadectw niektórzy badacze zaczynają uważać, iż liczba dowodów popierających teorię powstania bluesa na terenach ściśle wiejskich jest dość ograniczona. W. C. Handy w swoich wspomnieniach z 1941 roku opisał sytuację, kiedy pierwszy raz usłyszał muzykę bluesową wykonywaną przez „wychudzonego niewidomego artystę na stacji kolejowej w Tutwiler, Missisipi”23. Przez wiele lat opis ten służył jako dowód, iż muzyka bluesowa ma swoje korzenie w delcie Missisipi. Obecnie teoria ta jest kwestionowana $\mathrm{z}$ kilku powodów, wśród których wymienia się zarówno odległy czas pomiędzy zaistniałą sytuacją a jej relacjonowaniem, jak również fakt zastosowania przez owego muzyka techniki gry na gitarze rozpowszechnionej wśród wykonawców wodewilowych. Zwraca się także uwagę na fakt, iż publikacja wspomnień zbiegła się w czasie z koncertem muzyki afroamerykańskiej w słynnej hali koncertowej Carnegie Hall. W czasie zaś tego wydarzenia, organizowanego zresztą przez wpływowego producenta nagrań, ukazywano muzykę bluesową jako prekursora jazzu na terenach rolniczych Missisipi.

Skąd w takim razie wywodzi się blues? Brakuje wywiadów z wykonawcami urodzonymi przed 1900 rokiem, a informacje na temat artystów, którzy zaczęli działać w latach 30. ubiegłego wieku, pojawiły się dopiero 30-40 lat później. W posiadaniu naukowców znajdują się natomiast informacje odnośnie do bluesa wykonywanego w Coahoma County w latach 1941-1942. Przeprowadzano wówczas wiele wywiadów i ankiet wśród mieszkańców tego terenu oraz artystów tam działających. Niestety do

${ }^{22}$ W 1990 roku University Press of Mississippi wydało książkę Juke Joint autorstwa Birneya Imesa, zawierającą zdjęcia tego typu lokali. Obecnie są one przedmiotem badań antropologów kulturowych jako element dziedzictwa narodowego, a tym samym czynnik kształtujący tożsamość danej społeczności.

${ }^{23}$ Tłumaczenie własne z: D. Monod, „Ev'rybody’s Crazy „Bout the Doggone Blues”. Creating the County Blues in the Early Twentieth Century, „Journal of Popular Music Studies" 19 (2007) nr 2, s. 191. 
chwili obecnej nie zachowało się wiele ze zgromadzonych materiałów, ale nawet $\mathrm{z}$ tego, co pozostało można uzyskać szereg ciekawych informacji.

Okazuje się, iż większość z tych artystów wprowadzała rozróżnienie pomiędzy tzw. starym i nowym bluesem. Niektórzy podkreślali, że muzykę wykonywaną przed latami 20. stanowiły coon songs. Często pod pojęciem bluesa rozumieli oni również stare utwory wodewilowe, komponowane jeszcze w końcu XIX wieku. Blues pojawił się dopiero w latach 20. ubiegłego stulecia. Co więcej, wcześniejsze utwory wplecione w tradycję muzyczną tego terenu były tylko w stopniu ograniczonym powiązane z tym, co obserwowano w bluesie lat 40 . Niektórzy artyści twierdzili nawet, że muzyka bluesowa powstała na bazie ballad.

Kwestią problematyczną pozostawało więc to, w jaki sposób blues rozprzestrzenił się na tereny rolnicze. Otóż obszary te nigdy nie podlegały całkowite izolacji. Już we wczesnych latach 20 . większość małych miasteczek miała bowiem sceny, na których wystawiano wodewile. Różnego rodzaju trupy przemierzały tereny Południa, zapewniając mieszkańcom wyczekiwaną rozrywkę. Zaś w okresie zbiorów rolnicy musieli przywieść plony do miast i tam też wydawali swoje pieniądze, a robotnicy przemieszczali się z miejsca na miejsce w poszukiwaniu pracy. W. C. Handy wspominał, iż zwyczajowo w sytuacji otwarcia nowego sklepu jego właściciel organizował w nim występy muzyczne. Artyści rozpowszechniali wówczas słowa swoich utworów. Z czasem zaś pojawiły się gramofony, a wraz z nimi nagrania utworów muzycznych. Pomimo wysokiej ceny płyt, muzyka stawała się coraz bardziej dostępna dla Afroamerykanów, z których coraz więcej posiadało urządzenia do jej słuchania. Można też było uczestniczyć w występach we wspomnianych wcześniej juke joints. Wszystko to sprzyjało rozpowszechnianiu i modyfikowaniu starych trendów muzycznych i wprowadzaniu nowych.

W procesie tym duży nacisk kładziono na indywidualizację i podkreślenie własnej tożsamości, poprzez nadanie utworom pierwiastka odróżniającego danego artystę, a także nowe trendy w bluesie. Już przed 1925 rokiem wytwórnie płytowe produkowały reklamy nagrań, w których skupiano się na podkreślaniu nowatorskich elementów w muzyce bluesowej. Coraz większe firmy fonograficzne przejmowały powoli rynek płytowy. Taka sytuacja trwała aż do kolejnego etapu historii USA, który odcisnął 
swoje piętno na dziejach bluesa - Wielkiego Kryzysu, jaki miał miejsce w latach 1929-1933²4. Upadek rynku płytowego spowodował wówczas wygaśnięcie wersji bluesa $\mathrm{z}$ lat 20. Uznani wykonawcy w poszukiwaniu zarobku musieli bowiem wrócić do medicine shows lub też występować w trakcie lokalnych festynów. Pojawił się natomiast swing, który zawładnął rynkiem muzycznym USA. W tej sytuacji wcześniejsze utwory bluesowe modyfikowano na potrzeby nowego trendu. Zmiany następujące w kulturze i obyczajowości znów odzwierciedlały się w muzyce.

I tutaj zaistniało zjawisko, które w konsekwencji doprowadziło do problemów z określeniem, czym tak naprawdę jest blues i skąd się wywodzi. Folkloryści - przekonani zapewne o wartości tego gatunku muzycznego w procesie kształtowania tożsamości zarówno jednostki, jak i grupy społecznej - podjęli bowiem działania zmierzające nie tylko do jego zachowania, ale także do wydzielenia z niego elementów tradycji. W tym celu odnaleziono artystów, których poproszono o wykonywanie utworów należących do grupy tzw. starego bluesa. Jednakże znali oni tylko dzieła powstałe już w latach 20. XX wieku. W rezultacie badacze folkloru stworzyli podział geograficzny odpowiadający konkretnym sposobom wykonywania muzyki bluesowej. Być może dzięki temu doszło do wyróżnienia bluesa terenów rolniczych i terenów miejskich, ze szczególnym podkreślaniem wartości tego pierwszego jako bardziej autentycznego. Należy jednak pamiętać, że muzyka bluesowa jest bardzo silnie osadzona w dziejach historii USA, a jej powstanie, rozwój oraz następujące po sobie schyłki i wzrosty są ściśle powiązane z dziejami kraju. Muzyka ta tworzyła się wraz z rozwojem miast, zmieniała swój charakter wraz z przemieszczaniem się jej wykonawców, poruszała tematy bliskie jej słuchaczom.

Jak pisze w swoim artykule David Monod, badacz kultury USA wczesnych dekad XX wieku, nawet kontrowersje towarzyszące odkrywaniu jej korzeni nie powinny przesłonić jednego faktu - muzyka ta odegrała olbrzymią rolę ze względu na swoją polityczną, a także społeczną wartość. Była ona też powiązana $\mathrm{z}$ walką o prawa człowieka. Nie należy również

${ }^{24}$ Przyczyny i skutki wielkiego kryzysu ekonomicznego w USA przeanalizowano m.in. w: M. N. Rothbard, Wielki kryzys w Ameryce, tłum. M. Zieliński, W. Falkowski, Warszawa 2010. 
pomniejszać roli wykonawców bluesa poprzez sprowadzanie ich do prostych odtwórców i naśladowców. Muzyka ta była częścią ich kultury, a teksty utworów i sposoby ich wykonania kształtowały poczucie tożsamości oraz wzmacniały więzi grupowe.

\section{Podsumowanie}

Mottem artykułu jest fragment wystąpienia papieża Jana Pawła II, które miało miejsce w siedzibie UNESCO w Paryżu 2 czerwca 1980 roku. Mimo że słowa te padły już dawno, doskonale wpisują się one w wydźwięk terminu tożsamość, rozbudowując podawaną w słownikach definicję tego wyrazu. Natomiast kształtowanie tożsamości narodu odbywa się dzięki kulturze. To ona bowiem jest ogniwem spajającym poszczególne jednostki i dającym im poczucie przynależności. Dzięki kulturze dochodzi do społecznych interakcji, a także integracji grup istniejących w danej społeczności. Zaś jedną z dziedzin kultury jest muzyka. Autentyczność postaw prezentowanych w dziełach muzycznych wynika z tego, że źródłem siły społeczności jest poczucie jej tożsamości, wspólnotowość i zbiorowość. Taką funkcję spełnia do dziś muzyka bluesowa, która pomimo swych burzliwych dziejów oraz szeregu wątpliwości odnośnie do jej powstania przez milionów ludzi na całym świecie kojarzona jest $\mathrm{z}$ południem USA. Muzyka ta wyrosła z ludzi zamieszkujących określony teren, ich zwyczajów, postaw, obrzędowości, pracy. Stanowi świadectwo ich tożsamości. Potwierdzeniem tej tezy niech będą słowa wypowiedziane przez twórców muzyki bluesowej.

[Biali wykonawcy bluesowi] nigdy nie mogą być prawdziwymi bluesmanami $[\ldots]$

Co odróżnia artystę bluesmana od zwykłego wykonawcy, to kulturowo-rasowe cechy, jakie mogą być tylko odziedziczone przez potomków byłego amerykańskiego niewolnika ${ }^{25}$. s. 11.

5 Tłumaczenie własne z: B. Brunning, Blues. The British Connection, New York 1986, 
Żaden biały człowiek [...] ani też kolorowy nie może tworzyć prawdziwego bluesa, o ile nie urodził się i nie wychował na Południu ${ }^{26}$.

Słuszne wydaje się założenie, że wypowiedzi te doskonale oddają to, czym jest blues. To doświadczenie nabyte od przodków, sposób myślenia, zachowania, czyli to wszystko, co łączyło ich wykonawców i słuchaczy. Blues zespolił różne warstwy społeczne i stanowił ważny element w tworzeniu tożsamości czarnoskórych mieszkańców południowych stanów USA.

\section{Bibliografia}

Adult U., Black, White, and Blue: Racial Politics in B.B. King's Music from the 1960s, „The Journal of Popular Culture” 44 (2011) nr 2, s. 195-214.

Berkin C., Making America a history of the US, Wadsworth 2011.

Berlin I., Pokolenia w niewoli. Historia niewolnictwa w Ameryce Pónocnej, przeł. D. Cieśla, Warszawa 2010.

Brunning B., Blues. The British Connection, New York 1986.

Dąbkowski G., Europejska terminologia muzyczna, Kielce 1997.

Muzyka: kompozytorzy i wykonawcy, prądy i kierunki, dzieła, red. B. Kaczorowski, Warszawa 2007 (Encyklopedia PWN).

Eyerman R., Music in Movement: Cultural Politics and Old and New Social Movements, „Qualitative Sociology” 25 (2002) nr 3, s. 446-447.

Goodman N., Wstęp do socjologii, przekł. J. Polak, J. Ruszkowski, U. Zielińska, Poznań 2009.

Jan Paweł II, Pamięć i tożsamość, Kraków 2005.

King D., „The World's Against Me As A Black Man”. Charles Mingus and Segregated America, „Journal of Historical Sociology” 13 (2000) nr 1, s. 54-77.

Marcus K. H., Music and American Culture, „History Compass” 5/4 (2007), s. $1412-1430$.

${ }^{26}$ Tłumaczenie własne z: D. Monod, „Ev'rybody’s Crazy..., dz. cyt., s. 201. 
Monod David, „Ev'rybody's Crazy 'Bout the Doggone Blues”. Creating the County Blues in the Early Twentieth Century, „Journal of Popular Music Studies" 19 (2007) nr 2, s. 179-214.

Rothbard M. N., Wielki kryzys w Ameryce, tłum. M. Zieliński, W. Falkowski, Warszawa 2010.

Rozbicki M. J., Narodziny narodu, Warszawa 1991.

Rusinowa I., Tom czy Sam. Z dziejów Murzynów w Ameryce Pólnocnej, Warszawa 1983.

\section{Netografia}

About Medicine Shows, http://www.folkstreams.net/context,136 (30.10.2016).

Blues quotes, http://www.brainyquote.com/quotes/keywords/blues.html (02.11.2016).

Coon, http://slownikhistoryczny.pl/angielsko-polski/coon (10.08.2016).

Dziewiecki M., Psychologiczne interpretacje tożsamości człowieka, http://www. opoka.org.pl/biblioteka/I/IP/tozsamosc_czlowieka.html (20.11.2016).

The Deep South States, http://www.deep-south-usa.com/ (02.10.2016).

Field Hollers, http://northbysouth.kenyon.edu/2002/Music/Pages/fieldhollers. htm (13.11.2016).

Ralph Ellison quotes, http://www.goodreads.com/author/quotes/7508.Ralph_ Ellison (10.11.2016).

Słownik Języka Polskiego, http://sjp.pwn.pl/slownik/2530211/to\%C5\%BCsamo\%C5\%9B\%C4\%87 (03.11.2016).

\section{Abstract}

Scholars in American cultural history, ethnic studies, folklore, and musicology have increasingly placed music in its social and cultural context. This article surveys recent scholarship on popular music, country music and classical music, with an interest in determining how race and ethnicity, gender, and class have influenced the performance and production of music. This interdisciplinary research has illuminated issues as diverse as ethnic and regional identity, the degree of agency 
among artists, and Cold War politics. Despite some shortcomings in its application, such research continues to offer scholars much material regarding the many connections between music and American culture.

Słowa kluczowe: blues, USA, kultura, tożsamość, Afroamerykanie

Keywords: blues, USA, culture, identity, African-Americans 